\title{
Recognition of Relevant ORP, pH, and DO Bending Points in Ammonia Removal from Drinking Water through Online BAF System
}

\author{
Hassimi Abu Hasan, Siti Rozaimah Sheikh Abdullah, Siti Kartom Kamarudin, \\ and Noorhisham Tan Kofli
}

Department of Chemical and Process Engineering, Faculty of Engineering and Built Environment, Universiti Kebangsaan Malaysia, 43600 UKM Bangi, Selangor, Malaysia

Correspondence should be addressed to Hassimi Abu Hasan, simiabuhasan@gmail.com

Received 1 November 2010; Accepted 21 December 2010

Academic Editor: D. Yu. Murzin

Copyright (C) 2010 Hassimi Abu Hasan et al. This is an open access article distributed under the Creative Commons Attribution License, which permits unrestricted use, distribution, and reproduction in any medium, provided the original work is properly cited.

This study was undertaken to identify the relevant bending points in ORP, $\mathrm{pH}$, and DO profiles in ammonia removal through online monitoring. A novelty BAF system as newl application for drinking water treatment that equipped with $\mathrm{ORP}, \mathrm{pH}, \mathrm{DO}$ $\mathrm{NH}_{4}{ }^{+}$and $\mathrm{NO}_{3}{ }^{-}$sensors was used. Two types of polluted drinking water strength (low and high strength) with various $\mathrm{NH}_{4}{ }^{+}$ concentrations and aeration flow were treated at a fixed-time reaction of $24 \mathrm{~h}$. Experiments were conducted at four track studies (TS) of TS1 $\left(\mathrm{NH}_{4}{ }^{+}=50 \mathrm{mg} / \mathrm{L}\right.$, aeration $\left.=0.3 \mathrm{~L} / \mathrm{min}\right), \mathrm{TS} 2\left(\mathrm{NH}_{4}{ }^{+}=100 \mathrm{mg} / \mathrm{L}\right.$, aeration $\left.=2.0 \mathrm{~L} / \mathrm{min}\right), \mathrm{TS}\left(\mathrm{NH}_{4}{ }^{+}=100 \mathrm{mg} / \mathrm{L}\right.$, no aeration) and TS4 $\left(\mathrm{NH}_{4}{ }^{+}=10 \mathrm{mg} / \mathrm{L}\right.$, aeration $\left.=0.1 \mathrm{~L} / \mathrm{min}\right)$. The results showed that the removal of $\mathrm{NH}_{4}{ }^{+}$was more than $95 \%$ for TS1, TS2, and TS4. From the online monitoring performances, DO elbow and ammonia valley appeared in ORP and pH profiles, respectively. Similarly, new positive plateaus were observed in DO, indicating that the nitrifiers stopped to consume the DO after $\mathrm{NH}_{4}{ }^{+}$was completely removed. Hence, based on the bending points, the aeration system is possible to be automatically stopped just after DO elbow and ammonia valley appears in order to save the energy consumption and to shorten the time demands for the drinking water treatment process.

\section{Introduction}

The presence of ammonia in drinking water exceeding the Malaysian regulated limit $(<1.5 \mathrm{mg} / \mathrm{L})$ became a major problem to drinking water treatment plants (DWTPs). Recently, there is no specific treatment system that can remove the pollutant efficiently which finally causes plant shutdown for a period of time. Consequently, the populations in the area will face a shortage in water supply and interruption in almost daily activities. Moreover, high ammonia level in drinking water provided a complication on chlorination process due to the yield of chloramines [1], human nervous system damage and created a deteriorating taste and odour of water [2]. Therefore, it is necessary to develop an effective additional water treatment system, typically for ammonia removal in order to prevent the plant shutdown due to the high level of ammonia in water.
Based on the literature, biological aerated filter (BAF) is a suitable process as an additional system in DWTPs where the system is well known as one of the biological treatment systems in wastewater treatment but not in drinking water treatment. The BAF system is an attached growth process where consortium microorganisms grow on media which are stationary during normal operation with aeration $[3,4]$. Among the outstanding advantages of BAF are that it is a flexible reactor and able to perform solids separation as well as aerobic biological treatment, the space requirement for the treatment is also small [5] and it serves as a small footprint with a large surface area, simple construction and has ability to treat high organic loads [6]. Previous researchers [711] reported that almost and over $90 \%$ of ammonia was eliminated from wastewater by using BAF system. However, an effective performance can be only achieved with higher removal at optimum operational conditions such as short 


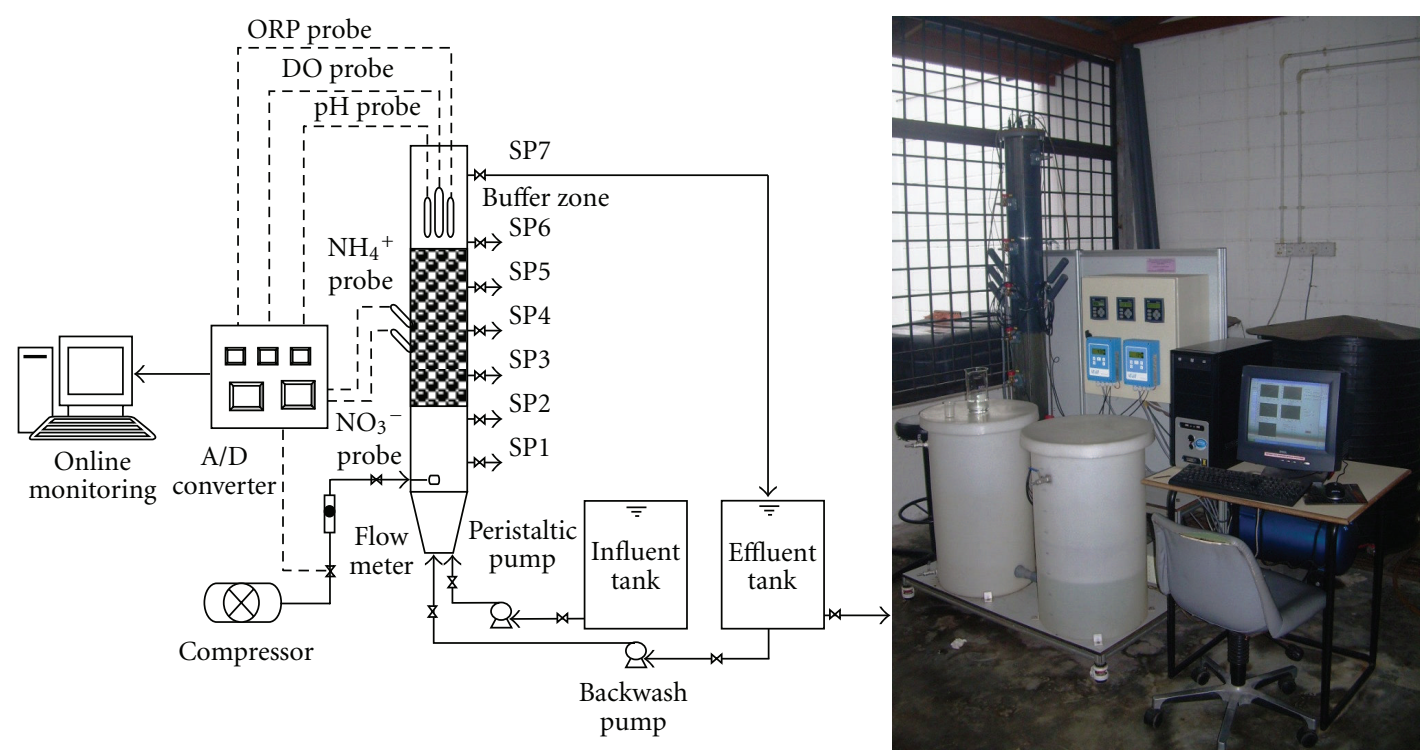

FIGURE 1: Schematic details of BAF equipped with online monitoring tools.

hydraulic retention time (HRT) and less electrical energy consumption for aeration. Thus, online monitoring can be used as a tool to control the biological ammonia removal from drinking water using BAF system.

Recently, online monitoring using $\mathrm{pH}$, oxidation reduction potential (ORP), and dissolved oxygen (DO) as parameters to control the biological nutrient removal has received much attention [11-14]. The ORP and DO levels can successfully indicate the oxidative and biological state of the wastewater, and $\mathrm{pH}$ is a good indicator of ongoing biological reactions [15]. The increasing interest toward the online monitoring is due to some advantages, that is, the biological nutrient removal can be controlled through relevant points such as ammonia valley and nitrate knee, it can be used to optimise the aerobic stage where the aeration can be stopped whenever nitrification is completed and subsequent anaerobic stage can be avoided when denitrification is completed [16].

ORP is the electromotive force developed when oxidizers or reducers are present in water. Compared with DO, ORP regulation is more in tune with the process dynamics, since many biological substances correlate with ORP values. In addition, protons generated in nitrification lowered $\mathrm{pH}$ values. Therefore, the ORP and $\mathrm{pH}$ have been commonly studied for real-time monitoring and control of activated sludge process [13, 17-19]. Particularly, several researchers have identified the "ammonia valley" in $\mathrm{pH}$ profiles and the "nitrogen break point" or the "DO elbow" in ORP profiles, which indicate the end of nitrification and the "nitrate knee" in ORP profiles and the "nitrate apex" in $\mathrm{pH}$ profiles indicating the end of denitrification process [11, 16, 19-21]. Corresponding to the bending point recognition, it was able to monitor the biological ammonia removal to save electrical energy consumption particularly during aeration phase [16].

To the best of knowledge, there is lacking information in online monitoring of ammonia removal from drinking water using BAF system, where most of the studies are mainly focused on using a sequencing biological reactor (SBR). Therefore, the aim of this study is to monitor and identify the relevant bending point in the $\mathrm{pH}, \mathrm{ORP}$, and $\mathrm{DO}$ profiles through online monitoring at various loading rates and operating conditions.

\section{Materials and Methods}

2.1. Synthetic Drinking Water. Synthetic polluted drinking water was prepared as feeding by using tap water. The water consists of glucose $\left(\mathrm{C}_{6} \mathrm{H}_{12} \mathrm{O}_{6}: 100-1000 \mathrm{mg} / \mathrm{L}\right)$, ammonium sulphate $\left(\left(\mathrm{NH}_{4}\right)_{2} \mathrm{SO}_{3}: 10-100 \mathrm{mg} / \mathrm{L}\right)$, sodium bicarbonate $\left(\mathrm{NaHCO}_{3}: 100 \mathrm{mg} / \mathrm{L}\right)$, magnesium chloride $\left(\mathrm{MgCl}_{2} \cdot 6 \mathrm{H}_{2} \mathrm{O}\right.$ : $8 \mathrm{mg} / \mathrm{L}$ ), iron chloride $\left(\mathrm{FeCl}_{3} \cdot 6 \mathrm{H}_{2} \mathrm{O}: 0.3 \mathrm{mg} / \mathrm{L}\right)$, manganese chloride $\left(\mathrm{MnCl}_{2} \cdot 4 \mathrm{H}_{2} \mathrm{O}: 2.0 \pm 0.1 \mathrm{mg} / \mathrm{L}\right)$, calcium chloride $\left(\mathrm{CaCl}_{2} \cdot 2 \mathrm{H}_{2} \mathrm{O}: 4.5 \mathrm{mg} / \mathrm{L}\right)$, and potassium dihydrogen phosphate $\left(\mathrm{KH}_{2} \mathrm{PO}_{4}: 2.5 \mathrm{mg} / \mathrm{L}\right)$. All the chemicals used are reagent grade salts (Systerm, Malaysia).

2.2. Bacteria Seeding. The seeding sewage activated sludge (SAS) as a degrading biofilm source used in the experiment was taken from a sewage treatment plant located in Putrajaya, Malaysia. The SAS is an effective bacteria source in which it contains more complex consortium of microorganisms, surface chemistry, large surface area, porosity, and excellent settling ability [22]. The SAS was acclimatised with sufficient energy source such as glucose $(200 \mathrm{mg} / \mathrm{L})$ and inorganic nutrients such as ammonia as nitrogen source $(40 \mathrm{mg} / \mathrm{L})$, phosphorus $(2.5 \mathrm{mg} / \mathrm{L})$, sulphur $(10 \mathrm{mg} / \mathrm{L})$, and trace elements (iron $0.3 \mathrm{mg} / \mathrm{L}$, manganese $0.3 \mathrm{mg} / \mathrm{L}$, and magnesium $8 \mathrm{mg} / \mathrm{L}$ ) for bacterial growth and enrichment [23]. Sodium bicarbonate $(100 \mathrm{mg} / \mathrm{L})$ as an external source of alkalinity was added at initiation of runs in order to prevent an insufficiency of the inorganic carbon that nitrifying bacteria require for their metabolism. 


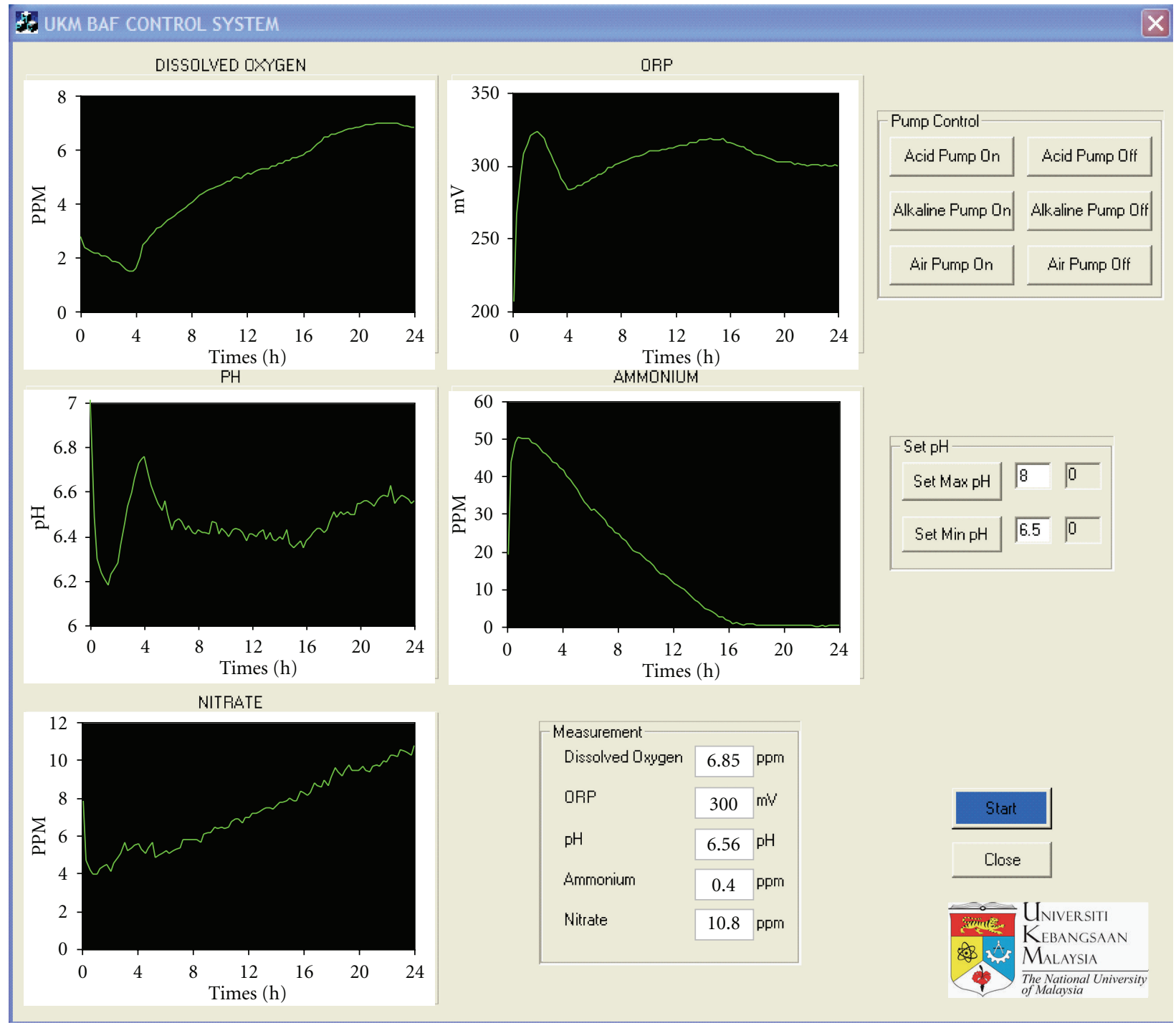

Figure 2: Online monitoring profiles as simulated by a Microsoft Visual C++ programming.

2.3. BAF Description and Track Studies. An upward flow configuration of a lab scaled BAF system was designed using transparent polyvinyl chloride (PVC) at a height of $150 \mathrm{~cm}$ and diameter of $16 \mathrm{~cm}$ with an effective working volume of $16 \mathrm{~L}$. The design was based on the data correlation of removal performances with BAF dimensions obtained from a previous study [24]. The schematic details are depicted in Figure 1. The system consisted of five main components, that is, BAF column, media, influent and effluent tank, influent and backwash pump, air compressor, and online monitoring set. At the top of the column, there was a buffer zone with $20 \mathrm{~cm}$ height to stop media from being carried away when treatment and backwash are operated. Sampling ports (SPs) were placed along the column height at $20 \mathrm{~cm}$ intervals for biomass and water sampling purposes.

The BAF was partially filled (about $12 \mathrm{~L}$ ) with a plastic media for nitrifiers growth and attachment. The media was made from polypropylene with dimension ratio $(\mathrm{H} / \mathrm{D})$ of 0.625 and density of $888 \mathrm{~kg} / \mathrm{m}^{3}$. The prepared feed from influent tank was flowed upward using a peristaltic pump (Masterflex, USA) at a flow rate of $580 \mathrm{~mL} / \mathrm{min}$ to occupy the BAF column in about 30 minutes. Aeration was supplied at the bottom of BAF column with an assistance of air compressor (PUMA XN2040, Taiwan). An air diffuser was used to distribute the air through the column in order to ensure homogenised condition. In the case of media clogging occurrence and maintenance of the nitrifier activity, the backwash system is subsequently operated by using water pump (CPm 158, Italy).

Investigation was divided to 4 track studies (TS1, TS2, TS3, and TS4). Each track study is varied in feed concentration (main interest: $\mathrm{NH}_{4}{ }^{+}$) and aeration rate. Table 1 showed the operating conditions where initial $\mathrm{pH}$ and HRT are maintained constantly at $\mathrm{pH} \mathrm{6-7} \mathrm{and} 24 \mathrm{~h}$ HRT. There are two strengths of simulated drinking water treated in this study. At TS1, high strength polluted drinking water (HSPDW) with concentration of $1000 \mathrm{mg} / \mathrm{L}$ COD and $50 \mathrm{mg} / \mathrm{L} \mathrm{NH}_{4}{ }^{+}$is fed where the COD: $\mathrm{NH}_{4}{ }^{+}$ratio 

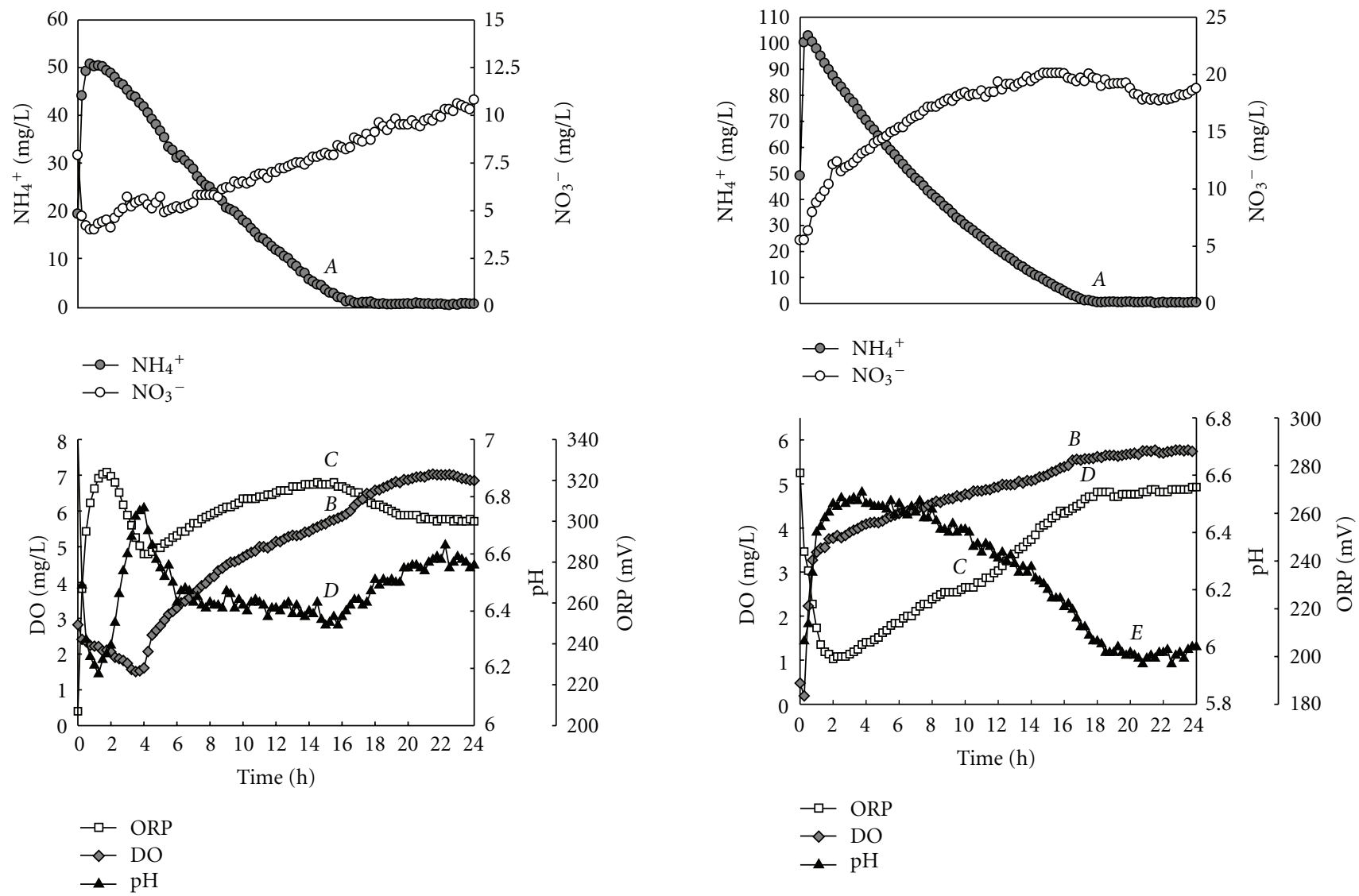

FIgURE 3: Online monitoring profiles from TS1 for $\mathrm{pH}$, DO, ORP, $\mathrm{NH}_{4}{ }^{+}$, and $\mathrm{NO}_{3}{ }^{-}$.

TABLE 1: Track studies of ammonia removal at various operating conditions.

\begin{tabular}{lcccc}
\hline Track studies & TS1 & TS2 & TS3 & TS4 \\
\hline Run $($ days $)$ & 13 & 10 & 7 & 10 \\
COD $(\mathrm{mg} / \mathrm{L})$ & $1000 \pm 29$ & $1000 \pm 33$ & $1000 \pm 15$ & $100 \pm 2.6$ \\
$\mathrm{NH}_{4}{ }^{+}(\mathrm{mg} / \mathrm{L})$ & $50 \pm 2$ & $100 \pm 5$ & $100 \pm 2$ & $10 \pm 0.26$ \\
$\mathrm{AR}(\mathrm{L} / \mathrm{min})$ & 0.3 & 2.0 & 0 & 0.1 \\
\hline
\end{tabular}

follows and the standard $\mathrm{C}: \mathrm{N}$ ratio of $100: 5$. At TS2, $\mathrm{NH}_{4}{ }^{+}$ concentration and AR were increased in order to observe the influence of DO. Another test (TS3) with no aeration flow was also conducted which consequently created an anaerobic condition in BAF column. At TS4, treatment was conducted for a low strength polluted drinking water (LSPDW), and in parallel a slower aeration flow is supplied.

2.4. Analytical and Online Monitoring Setup. COD was determined through digestion method at $150^{\circ} \mathrm{C}$ for 2 hours in $\mathrm{HACH}$ Reactor Digestion (HACH, USA) and measured by a spectrophotometer (HACH DR/2010, USA) at an absorbance of $620 \mathrm{~nm}$ (Method 8000). pH, ORP, and DO were continuously measured using pH (Model PD1R1 GLI, USA), ORP (Model PD1R1 GLI, USA), and DO (Model 5400 GLI, USA) probes connected to GLI meters (Model 33, USA),

FIGURE 4: Online monitoring profiles from TS2 for $\mathrm{pH}$, DO, ORP, $\mathrm{NH}_{4}{ }^{+}$, and $\mathrm{NO}_{3}{ }^{-}$.

respectively. Meanwhile, $\mathrm{NH}_{4}{ }^{+}$and $\mathrm{NO}_{3}{ }^{-}$were measured using Swansensor ammonium and Swansensor nitrate ion selective electrodes (ISE) and analysed through SWAN meters (FAM: Ammonium; FAM: Nitrate, Switzerland). All of the instruments were continuously calibrated depending on the sensors performance. An ORP value of $+200 \mathrm{mV}$ was used as a reference point to observe the oxidation length of the treatment period. For online monitoring, a program in Microsoft Visual C++ (Version 7.1.3088) software (USA) was set up. The A/D converter interface and data acquisition card (EX92026, Taiwan) provided the connection between $\mathrm{PC}$, meters ( $\mathrm{pH}, \mathrm{ORP}, \mathrm{DO}, \mathrm{NH}_{4}{ }^{+}-\mathrm{N}$ and $\mathrm{NO}_{3}{ }^{-}$), and air valve unit (Figure 1). Online mean values of $\mathrm{pH}, \mathrm{DO}, \mathrm{ORP}$, $\mathrm{NH}_{4}{ }^{+}$and $\mathrm{NO}_{3}{ }^{-}$were recorded for every $60 \mathrm{~s}$ as presented in Figure 2 .

\section{Results and Discussion}

The track study results of four typical batch runs are presented with the first three runs representative of the HPSDW (TS1, TS2, and TS3) and the last run representative of the LPSDW (TS4).

3.1. Track Study 1 (TS1). Figure 3 shows the profiles of TS1 and indicates that, for the $50 \mathrm{mg} / \mathrm{L} \mathrm{NH}_{4}{ }^{+}$fed at constant 

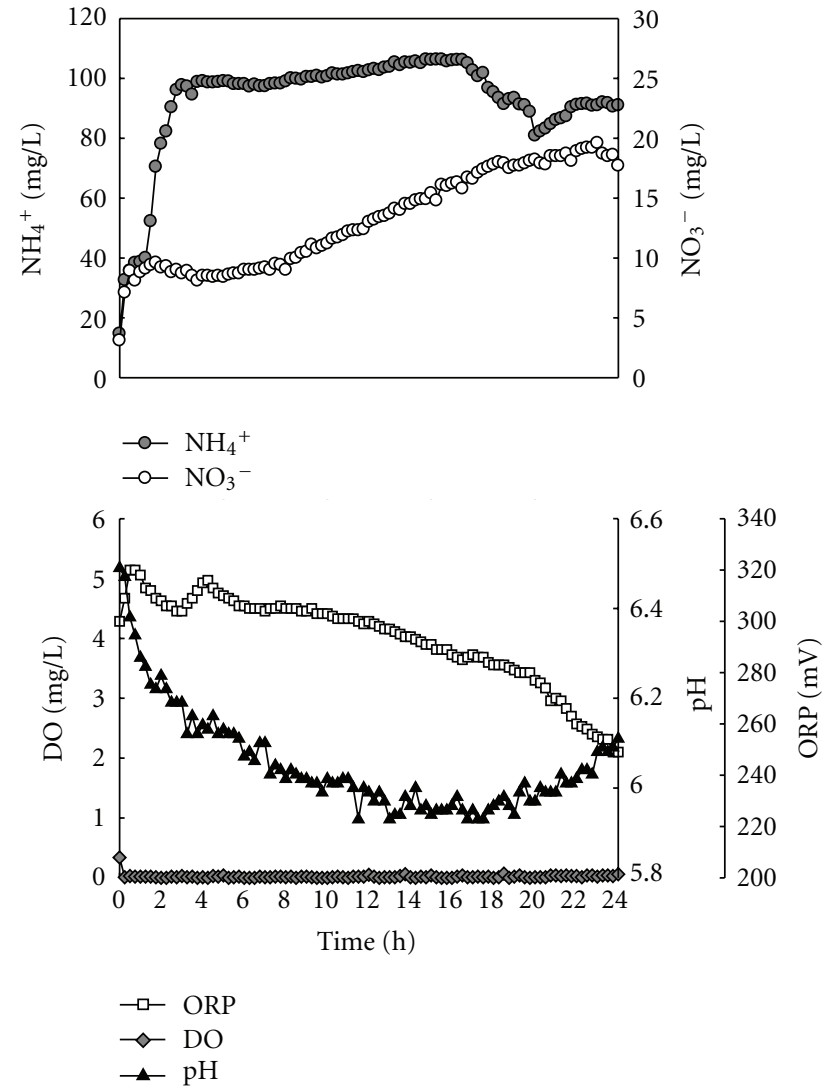

FIGURE 5: Online monitoring profiles from TS3 for $\mathrm{pH}$, DO, ORP, $\mathrm{NH}_{4}{ }^{+}$, and $\mathrm{NO}_{3}{ }^{-}$.

$0.3 \mathrm{~L} / \mathrm{min} \mathrm{AR}$, the complete $\mathrm{NH}_{4}{ }^{+}$removal occurred at the point $A$ (end of $16 \mathrm{~h}$ ). Along the removal process, the formation of $\mathrm{NO}_{3}{ }^{-}$was observed as increasing until the end of $24 \mathrm{~h}$ HRT. The common trends were due to continuous oxidation of $\mathrm{NH}_{4}^{+}$nitrite $\left(\mathrm{NO}_{2}^{-}\right)$and later to $\mathrm{NO}_{3}{ }^{-}$by nitrifiers with the assistance of sufficient DO. In DO profile, a distinct DO plateaus formed at point $B$ after $\mathrm{NH}_{4}{ }^{+}$was completely removed. The phenomenon shows that the consumption of DO by nitrifiers to oxidize the $\mathrm{NH}_{4}{ }^{+}$ is decreased, and therefore, the DO increased after point $B$ to a higher concentration. The clear appearance of point $C$ on the ORP profile is well correlated to DO elbow which indicates the end of nitrification process. In the mean time, $\mathrm{pH}$ values started to increase at point $D$. However, nitrate knee in ORP and the nitrate apex in $\mathrm{pH}$ profiles to indicate the end of denitrification process did not appear. This result is expected, because there was a fully aerobic condition in the BAF column besides the presence of excessive dissolved oxygen for $24 \mathrm{~h} \mathrm{HRT}$.

3.2. Track Study 2 (TS2). Figure 4 shows the profiles of TS2 and indicates that, for the $100 \mathrm{mg} / \mathrm{L} \mathrm{NH}_{4}{ }^{+}$fed at constant $2.0 \mathrm{~L} / \mathrm{min} \mathrm{AR}$, the stationary $\mathrm{NH}_{4}{ }^{+}$concentration was observed after $16 \mathrm{~h}$ of reaction time (point $A$ ), similar to TS1 profile. Again, once $\mathrm{NH}_{4}{ }^{+}$depleted, the DO plateau was also formed (point $B$ ) but this time only with slight significance.
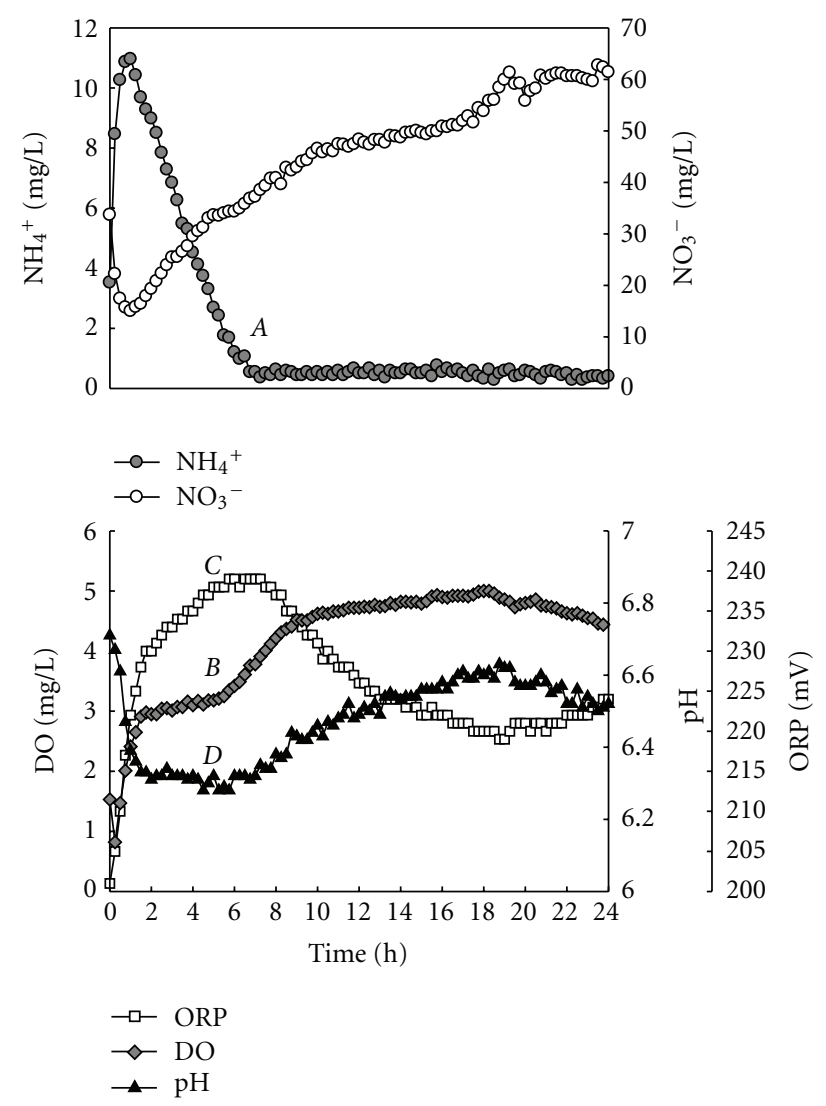

FIGURE 6: Online monitoring profiles from TS4 for $\mathrm{pH}$, DO, ORP, $\mathrm{NH}_{4}{ }^{+}$, and $\mathrm{NO}_{3}{ }^{-}$.

This is because the higher $\mathrm{NH}_{4}{ }^{+}$concentration is, the more DO will be consumed by nitrifiers for degradation.

Therefore, it can be seen from Figure 4 that the DO concentration was much lower compared with previous DO profile in TS1. For the ORP profile, two bending points were formed at points $C$ and $D$, indicating the end of nitrification stage and full oxidation status [25]. However, at point $C$, the remaining $\mathrm{NH}_{4}{ }^{+}$concentration was $25 \mathrm{mg} / \mathrm{L}$, and the oxidation process continuously occurred and started to level off at point $D$ which at the time, the concentration was below $0.5 \mathrm{mg} / \mathrm{L}$. Moreover, $\mathrm{pH}$ profile started to level off starting from point $E$, indicating that there is no more hydrogen ion produced [25].

The comparison of TS1 and TS2 results with other researchers using on-line BAF monitoring for ammonia removal could not be done. Most of the previous investigations only focused on using on-line SBR monitoring $[11-14,16,19,26]$ compared to other biological systems. Nevertheless, the obtained DO, pH, and ORP bending points in on-line BAF also show similarity to the theoretical principle especially ammonia valley ( $\mathrm{pH}$ profile) and DO elbow (ORP profile) which indicate the completion of a nitrification process.

3.3. Track Study 3 (TS3). Figure 5 presents the profiles of TS3 for the $100 \mathrm{mg} / \mathrm{L} \mathrm{NH}_{4}{ }^{+}$fed without aeration. As can 
be observed, the removal of $\mathrm{NH}_{4}{ }^{+}$did not occur without aeration compared with TS2, which was similar in both influent conditions. It was because DO was not sufficiently supplied to the nitrifiers in the BAF system which inhibited the nitrification process at low DO concentration $[27,28]$. Moreover, along the treatment period, DO concentration was almost zero which had created an anaerobic condition in BAF column. Through ORP profile, it be can strengthened that the removal of $\mathrm{NH}_{4}{ }^{+}$did not occur because the profile showed the decreased trend during the period.

3.4. Track Study 4 (TS4). Figure 6 illustrates the profile of DO, ORP, $\mathrm{pH}, \mathrm{NH}_{4}{ }^{+}$and $\mathrm{NO}_{3}{ }^{-}$under LSPDW $\left(\mathrm{NH}_{4}{ }^{+} \approx\right.$ $10 \mathrm{mg} / \mathrm{L}$ ) at aeration flow of $0.1 \mathrm{~L} / \mathrm{min}$. Generally, a lower $\mathrm{NH}_{4}{ }^{+}$concentration in water, a shorter HRT are required for complete degradation process. As can be seen in Figure 6, the $\mathrm{NH}_{4}{ }^{+}$profile was at steady-state condition starting from point $A$ (after $7 \mathrm{~h} H R T$ ) representing the complete removal. Meanwhile, $\mathrm{NO}_{3}{ }^{-}$continuously increased because the presence of $\mathrm{NH}_{4}{ }^{+}$residue in the water and also the denitrification process did not take place due to the excessive aeration period. When $\mathrm{NH}_{4}{ }^{+}$was completely removed, a new positive DO plateau was formed at point $B$, and after $9 \mathrm{~h}$ a steady-state concentration was achieved with $4.7 \mathrm{mg} / \mathrm{L}$. Moreover, DO elbow $(\mathrm{ORP}=+240 \mathrm{mV})$ and ammonia valley (pH 6.28) can be observed at points $C$ and $D$ in ORP and $\mathrm{pH}$, respectively. Since there are no more oxidation occurring and hydrogen ion being produced, ORP decreased to the lowest value of $+220 \mathrm{mV}$ while $\mathrm{pH}$ increased to a maximum value of 6.6. Therefore, as an effective $\mathrm{NH}_{4}{ }^{+}$ removal using BAF system for the optimum drinking water treatment operation, aeration can be stopped at $7 \mathrm{~h}$ HRT to allow denitrification process to take place and save energy of electrical consumption.

\section{Conclusions}

This study confirms that identification of bending point in ORP and $\mathrm{pH}$ profiles corresponding to DO elbow and ammonia valley clearly appears during the $\mathrm{NH}_{4}{ }^{+}$removal in novelty application of BAF system for drinking water treatment. Although various $\mathrm{NH}_{4}{ }^{+}$concentrations were fed to the BAF, the ORP, $\mathrm{pH}$ and $\mathrm{DO}$ showed a similar characteristic in ORP, pH, and DO profiles. From the bending point, the effective $\mathrm{NH}_{4}{ }^{+}$removal process can be maximized through the real-time control in order to prevent the excessive aeration and time demanding. The appearance of DO elbow and ammonia valley would give possibility to stop the aeration which consequently saves the energy. When no aeration was provided, the significant bending points were not observed and at the mean time the oxidation process did not occur. Therefore, the online monitoring tools can be used also in troubleshooting of the BAF operational especially when there is a problem in aeration system.

\section{Acknowledgment}

This paper was financially supported by the Ministry of Science, Technology and Innovation (MOSTI), Malaysia through Grant no. 02-01-02-SF0367.

\section{References}

[1] E. Okoniewska, J. Lach, M. Kacprzak, and E. Neczaj, "The removal of manganese, iron and ammonium nitrogen on impregnated activated carbon," Desalination, vol. 206, no. 1-3, pp. 251-258, 2007.

[2] W. R. Markesbery, W. D. Ehmann, M. Alauddin, and T. I. M. Hossain, "Brain trace element concentrations in aging," Neurobiology of Aging, vol. 5, no. 1, pp. 19-28, 1984.

[3] W. S. Chang, S. W. Hong, and J. Park, "Effect of zeolite media for the treatment of textile wastewater in a biological aerated filter," Process Biochemistry, vol. 37, no. 7, pp. 693-698, 2002.

[4] F. Liu, C. C. Zhao, D. F. Zhao, and G. H. Liu, "Tertiary treatment of textile wastewater with combined media biological aerated filter (CMBAF) at different hydraulic loadings and dissolved oxygen concentrations," Journal of Hazardous Materials, vol. 160, no. 1, pp. 161-167, 2008.

[5] D. Su, J. Wang, K. Liu, and D. Zhou, "Kinetic performance of oil-field produced water treatment by biological aerated filter," Chinese Journal of Chemical Engineering, vol. 15, no. 4, pp. 591-594, 2007.

[6] A. T. Mann and T. Stephenson, "Modelling biological aerated filters for wastewater treatment," Water Research, vol. 31, no. 10, pp. 2443-2448, 1997.

[7] S. H. Joo, D. J. Kim, I. K. Yoo, K. Park, and G. C. Cha, "Partial nitrification in an upflow biological aerated filter by $\mathrm{O}_{2}$ limitation," Biotechnology Letters, vol. 22, no. 11, pp. 937$940,2000$.

[8] T. Stephenson, S. J. T. Pollard, and E. Cartmell, "Feasibility of biological aerated filters (BAFs) for leachate treatment," in Proceedings Sardina, 9th International Waste Management and Landfill Symposium, Cagliari, Italy, 2003.

[9] J. H. Ha and S. K. Ong, "Nitrification and denitrification in partially aerated biological aerated filter (BAF) with dual size sand media," Water Science and Technology, vol. 55, no. 1-2, pp. 9-17, 2007.

[10] S. B. He, G. Xue, and H. N. Kong, "The performance of BAF using natural zeolite as filter media under conditions of low temperature and ammonium shock load," Journal of Hazardous Materials, vol. 143, no. 1-2, pp. 291-295, 2007.

[11] Z. Han, W. Wu, J. Zhu, and Y. Chen, "Oxidization-reduction potential and $\mathrm{pH}$ for optimization of nitrogen removal in a twice-fed sequencing batch reactor treating pig slurry," Biosystems Engineering, vol. 99, no. 2, pp. 273-281, 2008.

[12] B. S. Akin and A. Ugurlu, "Monitoring and control of biological nutrient removal in a sequencing batch reactor," Process Biochemistry, vol. 40, no. 8, pp. 2873-2878, 2005.

[13] D. Gao, Y. Peng, B. Li, and H. Liang, "Shortcut nitrificationdenitrification by real-time control strategies," Bioresource Technology, vol. 100, no. 7, pp. 2298-2300, 2009.

[14] Y. Cui, S. Wang, and J. Li, "On-line monitoring for phosphorus removal process and bacterial community in sequencing batch reactor," Chinese Journal of Chemical Engineering, vol. 17, no. 3, pp. 484-492, 2009.

[15] C. H. Ga and C. S. Ra, "Real-time control of oxic phase using $\mathrm{pH}(\mathrm{mV})$-time profile in swine wastewater treatment," Journal of Hazardous Materials, vol. 172, no. 1, pp. 61-67, 2009.

[16] G. Andreottola, P. Foladori, and M. Ragazzi, "On-line control of a SBR system for nitrogen removal from industrial wastewater," Water Science and Technology, vol. 43, no. 3, pp. 93-100, 2001.

[17] A. Spagni, J. Buday, P. Ratini, and G. Bortone, "Experimental considerations on monitoring $\mathrm{ORP}, \mathrm{pH}$, conductivity and dissolved oxygen in nitrogen and phosphorus biological 
removal processes," Water Science and Technology, vol. 43, no. 11, pp. 197-204, 2001.

[18] B. Li and P. L. Bishop, "Oxidation-reduction potential changes in aeration tanks and microprofiles of activated sludge floc in medium- and low-strength wastewaters," Water Environment Research, vol. 76, no. 5, pp. 394-403, 2004.

[19] N. Kishida, JU. H. Kim, M. Chen, H. Sasaki, and R. Sudo, "Effectiveness Of oxidation-reduction potential and $\mathrm{pH}$ as monitoring and control parameters for nitrogen removal in swine wastewater treatment by sequencing batch reactors," Journal of Bioscience and Bioengineering, vol. 96, no. 3, pp. 285-290, 2003.

[20] I. A. Al-Ghusain, J. Huang, O. J. Hao, and B. S. Lim, "Using $\mathrm{pH}$ as a real-time control parameter for wastewater treatment and sludge digestion processes," Water Science and Technology, vol. 30, no. 4, pp. 159-168, 1994.

[21] I. Al-Ghusain and O. J. Hao, "Use of $\mathrm{pH}$ as control parameter for aerobic/anoxic sludge digestion," Journal of Environmental Engineering, vol. 121, no. 3, pp. 225-235, 1995.

[22] J. Ye, H. Yin, B. Mai et al., "Biosorption of chromium from aqueous solution and electroplating wastewater using mixture of Candida lipolytica and dewatered sewage sludge," Bioresource Technology, vol. 101, no. 11, pp. 3893-3902, 2010.

[23] Metcalf and Eddy, Wastewater Engineering, Treatment and Reuse, McGraw-Hill, New York, NY, USA, 4th edition, 2004.

[24] H. A. Hasan, S. R. S. Abdullah, S. K. Kamarudin, and N. T. Kofli, "A review on the design criteria of biological aerated filter for cod, ammonia and manganese removal in drinking water treatment," Journal of Institution Engineers Malaysia, vol. 70, no. 4, pp. 25-33, 2009.

[25] R. F. Yu, S. L. Liaw, C. N. Chang, H. J. Lu, and W. Y. Cheng, "Monitoring and control using on-line ORP on the continuous-flow activated sludge batch reactor system," Water Science and Technology, vol. 35, no. 1, pp. 57-66, 1997.

[26] J. H. Kim, M. Chen, N. Kishida, and R. Sudo, "Integrated realtime control strategy for nitrogen removal in swine wastewater treatment using sequencing batch reactors," Water Research, vol. 38, no. 14-15, pp. 3340-3348, 2004.

[27] K. Pochana and J. Keller, "Study of factors affecting simultaneous nitrification and denitrification (SND)," Water Science and Technology, vol. 39, no. 6, pp. 61-68, 1999.

[28] W. Y. Dong, H. J. Wang, W. G. Li, W. C. Ying, G. H. Gan, and Y. Yang, "Effect of DO on simultaneous removal of carbon and nitrogen by a membrane aeration/filtration combined bioreactor," Journal of Membrane Science, vol. 344, no. 1-2, pp. 219-224, 2009. 

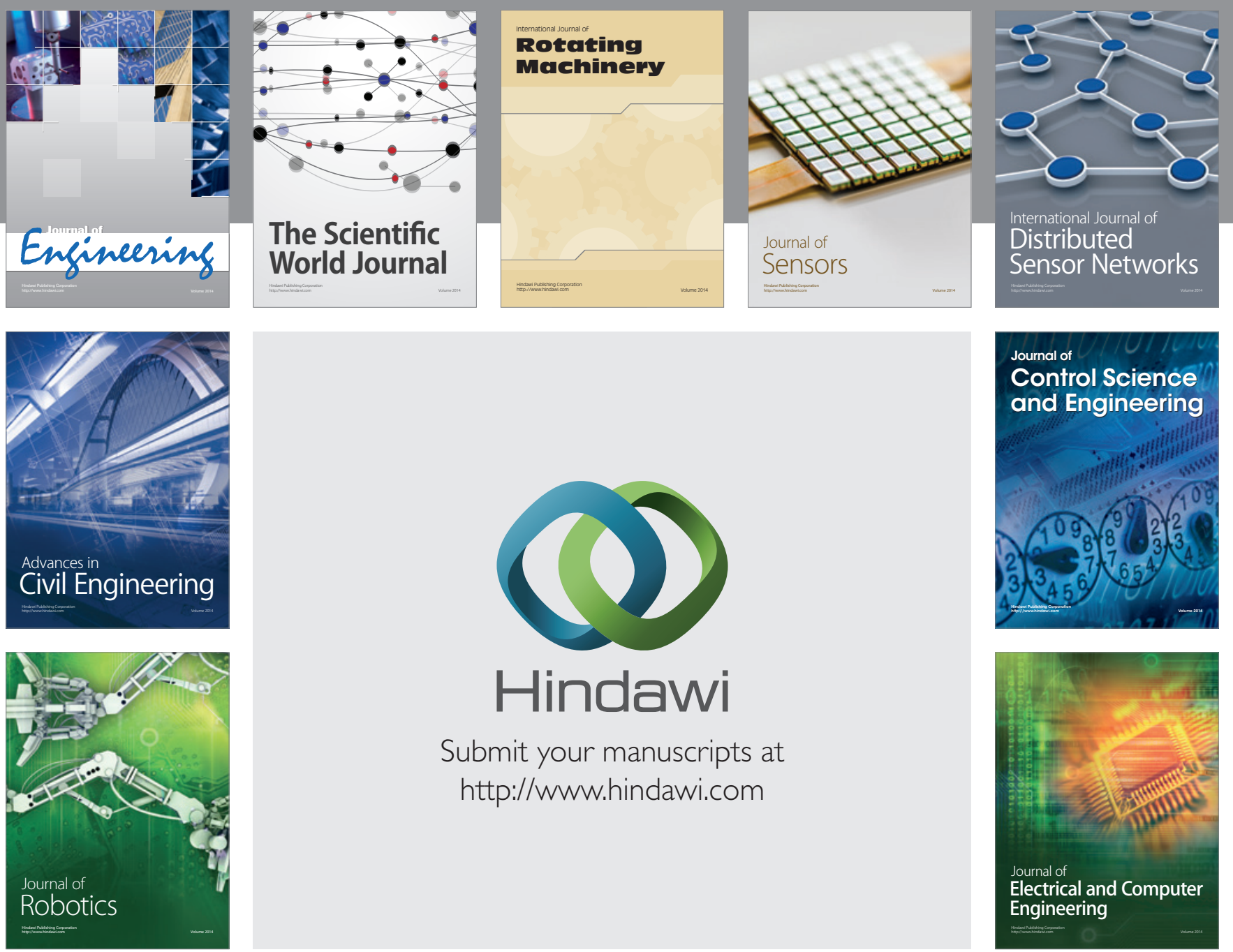

Submit your manuscripts at

http://www.hindawi.com
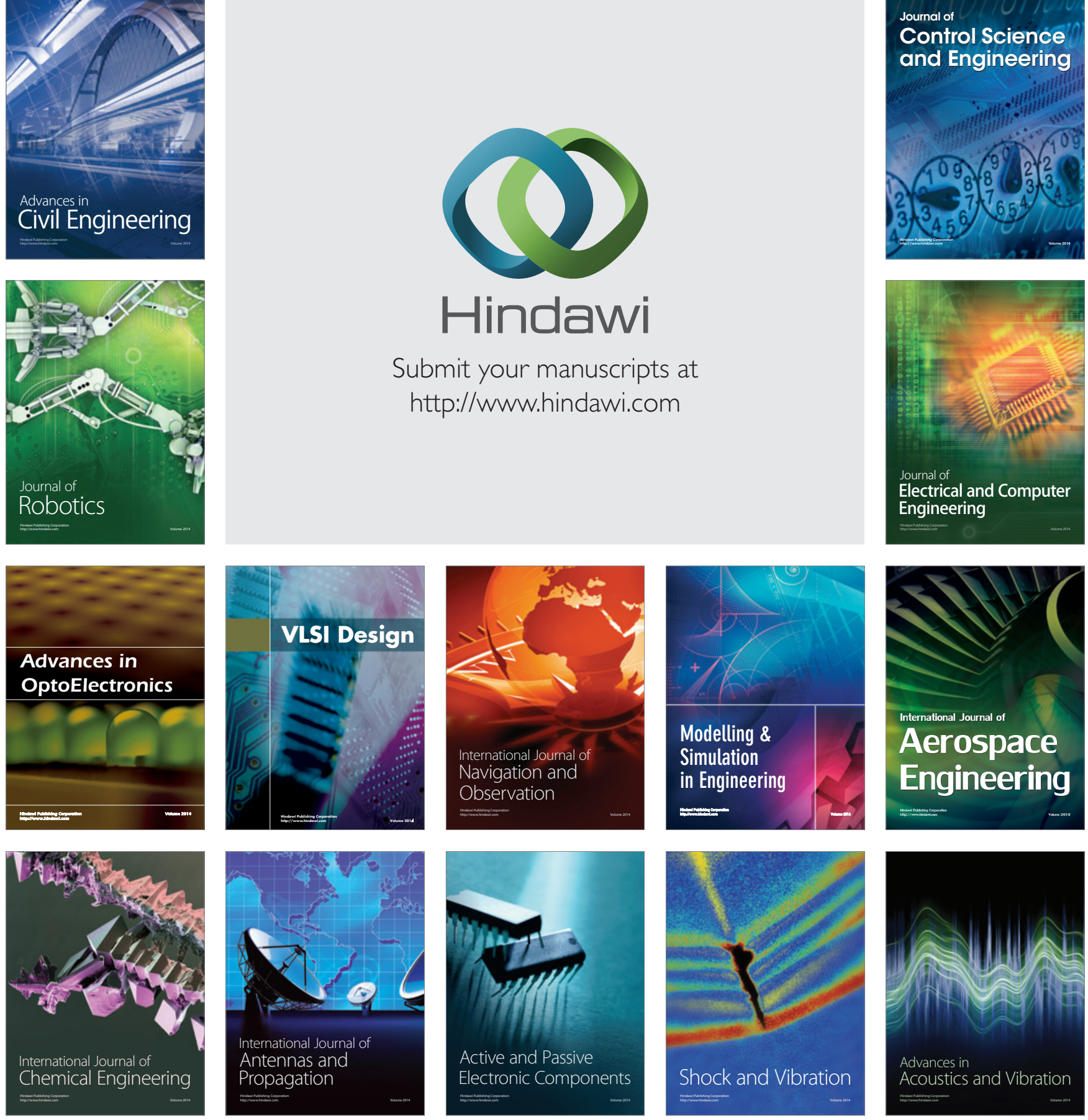